\title{
Sciendo
}

\section{Monsters, Disaster, and Organic Balance: Digesting History Through Oral Traditions}

\author{
THIERRY VEYRIÉ
}

American Indian Studies Research Institute and Department of Anthropology, Indiana University Bloomington, USA

tveyrie@iu.edu

\begin{abstract}
This paper examines "Coyote, Whirlwind, and Ravine," a long tale told in the Northern Paiute language by McDermitt storyteller Pete Snapp and recorded by folklorist Sven Liljeblad in the early 1960's. It weaves in traditional episodes of western Numic folklore to narrate the history of the Fort McDermitt Paiute-Shoshone community as witnessed by an elder born shortly after the beginning of the colonization of this area of the Northwestern Great Basin in the western United States. This paper explores how the bodies of certain characters who emanate from landscape, mainly monsters, are tools for the narrative expression of social change, for the telling of history, and the expression of Indigenous spiritual frameworks. It places the experience of the Indigenous social body, embodied by Coyote, through the grinds of the ultra-material Ravine and confronts it to ethereal nefarious powers. Poetics of materiality applied to the body of Coyote operate a structural transformation. Mythical turmoil expresses social experiences and change in the colonial context, but also makes manifest the transformation of the social body that result in the contemporary form of the Fort McDermitt Paiute-Shoshone community.
\end{abstract}

KEY WORDS: body, indigeneity, monsters, myth, Northern Paiute, oral history

An earlier version of this paper was presented at the 2017 meeting of the American Society for Ethnohistory in Winnipeg. I wish to thank our chair Regna Darnell and discussant Michael Harkin for their precious remarks, as well as Ian Puppe for having organized this session. I am also indebted to Jason B. Jackson, Tim Thornes, and Raymond J. DeMallie for providing comments on my manuscript, and to Cailín Murray for her suggestions during the review process. 


\section{Introduction}

Monsters are striking because of salient features, physical traits of manifest uncanny register. What distinguishes monsters is that they are so particular, and so diverse in these differences that they can be listed in a taxonomy of the bizarre (Foster 2008). When thinking about these creatures, one pictures deformed human bodies - the monstrous - or creatures further away from humanity, radical monsters whose physical appearance only remotely reminds us of who we are (Mori 2012). To be sure, monstre, the old French origin of the word monster, means 'to show.' The monster is thus the one so particular that people cannot take their eyes off of them, and even more stereotypically, that they would point at with their finger. ${ }^{2}$

The Paiute-Shoshone people are much more polite than the French about this. For one thing, you do not say bad things about supernatural creatures in order not to upset them. These creatures are powerful, and no one can escape their wrath if they feel offended. They dwell in places, may it be a spring, a cliff, or a deserted home. People are careful when they speak of them, or when they approach them, to be respectful and mindful of their power and right to occupy those places. Some individuals may even be able to negotiate with them, pray, and obtain some power from them.

The politeness that my Paiute friends show to monsters, I fancy also somewhat applies to me as an alien and an anthropologist. As a stranger, Paiutes distinctively ignore my presence, but they nevertheless watch me, an anomaly in their social normality. What is being an anthropologist if it is not being one's social monster, a creature so particular, with its notebook and its questions, its efforts to behave and speak like one people - often with much difficulty and many errors - an oddity of nature, not a perfect ally, and not an enemy?

Paiute stories explain how things came to be the way that they are, and thus have a singular historical purpose, but also serve to represent the reality of things and peoples of the world, and how to behave in relation to them. Scholars have long debated the historical function in Native American verbal arts (Lowie 1915; Bahr 2001), often questioning it on the grounds of validity. More recent studies have challenged the denial of historical validity in myth, beginning with Jan Vansina's analytical monograph Oral Tradition as History (1985). In the same vein as Jason Jackson (2013), I would argue that Robert Lowie and others may have had too narrow a concept of history to be able to appreciate the mediated history common in

2 Paiutes do not point with the finger. People, especially women, commonly point with their lips to give a direction, but this does not target an individual other than to be the recipient of an offering. 
Native myths. Alan McMillan and Ian Hutchinson $(2002,44)$ noted: "Oral traditions may have multiple levels of meaning, rather than describing a single set of historic events". Here I would like to explore how the bodies of certain characters, mainly monsters, are the grounds for the expression of social change, for the telling of history, and the expression of political ideology. I will explore the aesthetics of the body and how storytelling is a vehicle for telling and processing history as testified to in one unpublished tale by Fort McDermitt PaiuteShoshone storyteller Pete Snapp.

The literature on monsters is abundant. The more modest anthropological scholarship on monsters has sometimes been creative in finding a positionality that would authorize taking monsters seriously. Marjorie Halpin and Michael Ames (1980) for example edited a volume of investigations on humanlike monsters with an ironic yet evidence-based approach. Placing the human experience at the heart of anthropological research on monsters is indeed essential to reflect the diversity of ways with which monsters affect the lives of cultured individuals. In an introduction to another, more recent, edited volume on monsters, Yasmine Musharbash $(2014,1)$ stated: "Not only are our monsters different, but they are also real in different ways". Monsters are dwellers of our cultural worlds and hold in them unclear standing that make them powerful agents to questions our categories and unsettled our certitudes (Murray 2019). Monster narratives pertain to the expression of lived experience and as such are both unquestionable and difficult to decipher. I believe interpretive anthropology, the reconstruction of meaning from well fleshed cultural context and examination of selfrepresentation within this context (Geertz 1973), can provide tools to unravel some of the levels of meaning supported by those narratives.

The tale that is the object of this paper was told on the Fort McDermitt Paiute-Shoshone Reservation by Pete Snapp, probably in the early 1960's. The community is named after a military post that was built on the Quinn River in 1866 after Lieutenant-Colonel Charles McDermitt, the officer in charge of the security of the area, was killed in an ambush during the Snake War as he was entering the valley. His name was given to the nearby military camp and later to the town of McDermitt, and to the Native reservation. A stagecoach line operated between Boise and the Nevada settlements on the Humboldt River, with a stop near then Camp McDermitt. In 1889, at a time when the Secretary of War was trying to abandon the old forts of the West, Fort McDermitt was transferred to the Secretary of Interior to be turned into an Indian reservation with a school for the Paiutes. These events defined Pete Snapp's life, himself the product of the early days of frontier society in the Quinn River Valley. His 
father probably operated the Quinn River Station ${ }^{3}$ on the stagecoach line in the 1860's and 1870's, but Pete Snapp was raised by his Paiute mother. He was thus culturally Paiute and was widely recognized as an outstanding storyteller who had inherited oral tradition from his mother's family. He was born around 1871-1872, during the early settlement of the region but also when Paiute life was irremediably changing.

In this tale, Pete Snapp weaves traditional mythical sequences of Numic folklore into a singular and complex story. Traditional Numic storytelling commonly requires an interlocutor who regularly plays the opposition, asking for a clarification, repeating an action or the name of a character, or even anticipating the next sequence. The active listener shows in doing so that the story does not fall on deaf ears (Liljeblad 1986, 650; Lowie 1924b, 309; Veyrié 2021, 226-228). Pete Snapp's son Allen played this role when this story was recorded at a date unknown. Sven Liljeblad and Allen Snapp listened back to the story between April and June 1963 and translated it into English. Liljeblad filled, for this tale only, five notebooks with the interlinear transcription and translation on the left page, and comments on the right page. Pete Snapp articulates in this story seven traditional episodes of Northern Paiute folklore. In addition to being narratively autonomous, sequences are delineated by an enduring change at the end, often followed by a brief discussion with the interlocutor, and Coyote speaking arrogantly at the beginning of the following sequence. I represent them here with paragraphs. ${ }^{4}$

\section{Commented Summary of "Coyote, Whirlwind, and Ravine" by Pete Snapp 5}

This tale proposes an oral chronicle of the Indigenous dwellers of the valley. It starts with Pete Snapp's declaration "There were those people who lived right here in this region"

3 The Quinn River Station was referred to as the McCobley and Snapp Station in a letter sent on February $6^{\text {th }}$ 1867. In a letter dated October $7^{\text {th }} 1870$, Captain Wilson, Commanding Officer of Camp McDermit, reports demanding McCobley to vacate the Quinn River Station, and removed the troops guarding it.

4 This tale deserves more than the brief summary I am about to make, and can be found in its entirety as Appendix D of my doctoral dissertation (Veyrié 2021, 444-545). I hope that by shedding light on this tale we are working toward giving justice to Pete Snapp and Sven Liljeblad's work and bring their manuscripts, which include many other stories, to publication.

5 The tale was translated by Allen Snapp and Sven Liljeblad. University of Nevada, Reno (UNR), Special Collection 86-14, Box 25, MSS “Copy of texts in Northern Paiute" pp. 102-162, and the field notebooks 914. I would like to thank Jacqueline Sundstrand from the Special Collections for helping me dive into this 
presenting the story as an account of aboriginal history, of a bygone age but anchored in a place centered around the teller. Allen Snapp then asked if Pete was referring to the Quinn River Valley in its English name: kwiinorivowaitimma?a? (Quinn River -wai /arealis/ -t $\dot{t}$ /locative/ -mma?a /short distance demonstrative/ 'right here in the Quinn River area?'). The storyteller then confirms "They lived here," and adds, moving on, "and they did not like the whirlwind. 'The whirlwind is a bad one; since he often kills [people], let us send him away,' they said." The unspecified "they" refers, per the principle of indistinction that pervades Numic mythology (Veyrié 2021, 166), to the mythical people in which animal characters form a society analogous to the Paiute. Badger, reputed to be strong, is asked to take Whirlwind away. ${ }^{6}$ He captures him in a bag and ties it solidly but as he heads off to the east with it, he finds Coyote on his way who inquires about the fantastic powers of Whirlwind. Coyote persuades Badger to let him peek into the bag, but Badger digs a hole in which to hide while Coyote opens it. Whirlwind gushes out and throws Coyote out far away in the east where he lands, dead. Pete Snapp then comments that this is how Whirlwind went to the east [of the Rocky Mountains, referring to the common phenomenon of tornadoes] but that people worry that it might return some day. If Pete Snapp confirmed that he was referring most immediately to the Quinn River Valley, "here" is extensible and can refer more generally to the Great Basin, as a culturally homogenous and geographically bounded space. This traditional Numic mythological episode also appears in an article by Paiute storyteller Judy Trejo (1974, 67-8), but historic Paiute leader Naches told a version in which Whirlwind is the result of Badger's excavations (Powell 1971, 220).

Coyote stays there dead until the next spring. Here Allen Snapp interjects in Paiute: "Was that the time when the crow woke him up?" Yes, replies Pete Snapp, confirming the beginning of a new episode. Crow was pecking Coyote's carcass and that woke him up, a transition also used by Trejo $(1974,68)$. Unappreciative of being brought back to life, Coyote scolds Crow telling him that when one sees a friend still sleeping at noon, one should let him sleep on account of the wild night he must have had. Coyote then goes and sleeps around

archival collection, as well as Helen and Delora Snapp for sharing with me details of their grandfathers' (Pete and Sven were both considered as such) relationship and supporting my work in McDermitt. Finally, I am grateful of Carl and Astrid von Heijne, Sven Liljeblad's closest relatives, for authorizing the dissemination of his linguistic and ethnographic work.

6 Both Badger and Whirlwind are symbolically associated with mysterious harm. Badgers are said to be vulnerable to menstruating women (Veyrié 2021,261). According to Naches Whirlwind are a manifestation of a wandering ghost (Powell 1971, 246), Captain Louey referred to them as the manifestation of wicked sorcerers (Marsden 1972, 27). 
four times with the older sister of a sorority: ${ }^{7}$ with the black ant sister first, ${ }^{8}$ then with the wasp elder daughter, and with the scorpion older sister; and finally Coyote has an affair with porcupine. Each time his penis is bitten by his partners, resulting in gonorrhea (kunuza, most likely a borrowing from the English), and it worsens each time he has sex with a different partner. Between each intercourse, he removes and hides his swollen penis that gets found by the magpies who play with it. He gets the worst type of gonorrhea from Porcupine who whips his penis with its tail. "There [Coyote] brought [Gonorrhea] about." Trejo, in her account, also finds the origin of disease in Coyote's sexual freedom. ${ }^{9}$

The next episode stages Weasel who lost his younger brother while they were camping and eating deer. Desperate, he accuses and threatens everybody among the people ${ }^{10}$. The people decide to look for all the medicine men to find him, but the doctors fail in their attempt to locate Weasel's brother. Coyote volunteers to go with four medicine men to find Weasel's brother declaring that he is still alive in a ravine in which he got stuck after being caught by a deer head that tumbled down the hill. ${ }^{11}$ They get closer, the medicine men walking separately in line, and the Troglodyte People come to Coyote who pretends to be old, blind, ${ }^{12}$ and desiccated. They question him suspiciously, but they are unable to figure out his identity, although they suspect him to be Coyote. They offer him food and water to tempt the glutton to show his real face, but Coyote, having overheard them, controls himself. They then play a obsidian and kutsu cattle), the second one refers to small black ants according to Harold Able (Liljeblad, Fowler and Powell 2012, 46). My guess is that the first one also refers to a species of ants, obsidian then referring either to their black color or to the minerals these are habitually found nearby.

Trejo expands on the character of Itzaa waritsi "Old man Coyote", the "the dirty old man", explaining that the moral of these stories is about being understanding and kind with the elderly regardless of their attitude (Trejo 1974, 69).

This plot also comes up in three Shoshone tales (Lowie 1909, 254-261). In two of them, the giant is responsible for the abduction.

11 In a Kididikadi tale, after hunting a deer, Weasel had his brother-in-law Skunk eat a hot stone and dropped him over the cliff (Kelly 1938, 435). Lowie published a longer version of the same tale narrating social chaos resulting out of Weasel's murder of his brother-in-law Skunk (1924a, 234-41). The rolling skull or rock is one of the most common mythical motives across North America.

12 Coyote's blindness is a recurring theme of Northern Paiute folklore, although here Coyote is only pretending. More commonly, his blindness is the result of his juggling with his eyes and being stolen by birds (Lowie 1924a, 222; Kelly 1938, 418-419; Marsden 1923, 188-191). In this tale, the motif appears partially when the magpies play with his swollen penis. 
throwing game with him. Coyote plays blind for a few throws, and declares complacently that the projectile deserves its fate, revealing that they are playing with Weasel's brother. Coyote spits in his hands and rubs them to prepare for his first good throw, and once he receives the projectile, sends it over the hill where the medicine men were waiting. Coyote then runs away and eventually transforms into a buffalo track to lose his pursuers. These innovative deceptions displayed by Coyote resulted in the creation of scolding and blindness for all people. Each episode of the story introduces a new people over whom Coyote triumphs, ultimately to the expense of everyone.

Pete Snapp then starts an episode relative to the canyons. As Coyote was jumping over a narrow canyon, he does not quite reach the other end and starts complaining arrogantly to his tapeworms about the way the canyon is, and how it should be different. ${ }^{13}$ Coyote's five Siwo? ${ }^{14}$ give him reasonable advice and allow to narratively offer Coyote's internal point of view: Coyote shares with them how infatuated with himself he is being in a leadership position, vanity being a recurring trait of character for Coyote. A whistling character with a feather on his head comes from a canyon, this character is often known as Nimizoho, the People-Masher, and the Siwo?a tell Coyote to remove his skin to appear sick and abandoned, attracting the ogre's sympathy. The creature asks him what he wants to do, and they decide on a game of pounding each other's heads because Coyote is in no shape for any other game. The creature lets Coyote hit first, and once the monster blinks, Coyote then smashes his head telling him to let people die slowly, which results in people now declining rather than dying instantaneously.

Coyote then takes a break halfway up the hillside and remarks that he is the only leader of the place, prompting his Siwo?a's caution, that there is something worse coming. Coyote is teased by this reply and endeavors to investigate inside Ravine who he thinks might be his challenger. Coyote ties a willow to his side to keep the ravine's mouth open when he devours

13 As mentioned in the introduction to this chapter, Coyote commits a breach of Paiute ethics by complacently criticizing the ravine's distinctive features. A discussion of the Paiute code of conduct in places can be found in my dissertation (Veyrié 2021, 167-183).

14 Liljeblad translates siwo?a as tapeworms, perhaps a compound of sii 'intestines' - wo?a 'worm.' Paiute elder Dennis Smartt preferred to translate it as 'inner feeling' or 'intuition,' which shows the ambiguity of the word but also its definite positive symbolic value. Isabel Kelly (1938, 410-411) published a tale from Surprise Valley featuring Nimizoho and this helpful character as siwa? a, translating it as 'intestinal worms.' Marsden (1972, 37-41) recorded a version where a similar character is referred to in English as 'intestinal mucus,' but the Paiute word is not in the published version. The literal identification of this mythical character as an intestinal parasite is thusly attested among some Wadatika, Kididika, and McDermitt Paiute families, but its figurative meaning and symbolic role is more generally that of an inner spirit, or intuition. 
him. As he walks along, he feels that it gets darker and becomes blind. His youngest Siwo?a informs him that he is swallowed and that he should stand still protected by his willow stick, and to go and feel for a breath. The Siwo? a then tells him to follow the cold breath and to cut Ravine wide open using all his five knives, which explains why canyons now have edges and why roads can go through the bottom of them. ${ }^{15}$

In the next short episode, Coyote sat down to have a smoke and contemplate his leadership. Crickets came and Coyote fed on them. They suddenly fly away, and he decides to go in the opposite direction to inquire. He is warned by his Siwo?a that the big bear who eats people is coming, so he transforms into a little weasel to scare him. As they are afraid of each other and cannot come to a fight, they decide to both vomit to figure out who is the strongest from what they ate last. They agree to close their eyes to vomit and open them at the same time, but Coyote cheats and exchanges his cricket for the scapula Bear had vomited. Bear who never eats crickets is too embarrassed to question the perplexing result, lets Coyote go, but he changes his mind and decides to go after Coyote who transforms in a pine squirrel. Bear does not give up and Coyote goes to an area with holes in the ground and transforms into a spring. Bear twists his ankle in a hole and gives up, and this explains why the bears act this way now. A version published by Kelly $(1938,421)$ portrays Coyote's challenge to Bear who had killed his son. Coyote convinces her to go in opposite directions, and kills her by surprise. Bear's chase after Coyote also appears in different versions (Lowie 1909a, 277).

Coyote brags again of his commanding authority despite his Siwo?a's repeated warnings. His Siwo? a tell him about another dangerous enemy, a ghost who has an axe and a knife and lives in a cave on a hill. ${ }^{16}$ They tell him to make an axe out of resin and to put some in his flesh, and they advise him to repeat anything Ghost does or says when he attacks him. When they meet, Coyote repeats Ghost's words, and they agree to be friends. Ghost takes Coyote deep in his cave and asks for some of his flesh. After serving him some resin, Coyote reciprocates the request and, without waiting for an answer, cuts Ghost's lungs and heart, helping himself. Ghost, furious, runs after Coyote who invents darkness and storms to escape, without success.

15 I only found one other version of Coyote opening the cave that had swallowed him by attacking one of its organs (Kelly 1938, 414). Two traditional motives can however be identified: Coyote's blindness (Lowie 1924a, 221-222) and his disruption of the magical cave (Kelly 1938, 378-382; Marsden 1923, 180-184).

16 Ghost is not a common character in Numic folklore, which leads me to think that it could be a storytelling innovation. It is however a prevalent phenomenon that can explain sickness, or materialize in people's life (Lowie 1909a, 227). 
Finally, he invents burnt branches where Ghost gets stuck. ${ }^{17}$ Presented as his most dangerous opponent, Ghost reveals itself to be as deceptive as Coyote, asking if they could be friends when the action turns to Coyote's advantage. Coyote agrees to set him free only if they exchange their weapons. In a final betrayal, Ghost hits him but the resin axe explodes. Coyote then declares that Ghost should help cure people and as he has now lost his power, ${ }^{18}$ that the powerful one is somewhere on the other side, that a greater power now comes from Peyote who will be the medicine man for the Indian people and it will spread over the world. Although this sequence may be original from the part of Pete Snapp, the dispelling of a ghost by command appears in several Shoshone accounts (Lowie 1909a, 299-301).

This tale ends with another intriguing event setting it in a multi-layered Native history: after the errands of Coyote looking for powerful doctors (Puhagami) able to solve the problems his people are having, the tale concludes with the arrival of Peyote, a greater medicine that can save the Indians. The arrival of Peyote in McDermitt was dated to be in 1935 by Omer Stewart who conducted fieldwork in the community when investigating Peyote history (Stewart 1987, 290). In other words, Pete Snapp was already an elder when Peyote arrived to save the people. This tale appears as a unique synthesis between traditional folklore and oral history, as seen by an individual who witnessed and embodies the drastic change that Native peoples had to face with the arrival of new dwellers. As a narrative unit, this long tale narrates the spiritual errancy of the people between the eastern exile of a powerful life-threatening dweller, Whirlwind, and a symbolic return when Peyote, a new source of curative power, comes from the east. Coyote, paradoxical underlying expression of the Paiute cultural ethos, was brought back to life in the east, and the twists and turns of the tale narrate his efforts to improve a degraded situation. The people's perceived need of cultural revitalization is at the core of this oral history.

\section{Materiality Poetics}

This tale features two types of characters: animals and monsters. Animals, insects, and Siwo? a are common characters, no more different from humans than they are different to each other (Descola 2013, 130). Monsters on the other hand are more radically different, and

17 The motif of the obstacle flight is also recurring in North America. In it, a character tosses behind magical obstacles and traps for his pursuer.

18 The same power of disruption of ghosts from the part of the victim is related by Lowie (1909a, 227) as a recurring performative speech act to get rid of monsters. 
crucially in this story, they are outside of the social group: they live separate from the mythical animals and insects and can be unexpectedly deadly to them. Anthropologist Raymond Fogelson (1980, 147) more generally observed that monsters behave "anticulturally," and as such, "embody the realm of nature rather than culture". This relevant distinction however is carried here with a perspectivist dimension: disease, deadfall, aging the results of the interaction with monsters in this tale - reveal to be death imposed by the interaction with a third party alien to the social group in the same way as warfare, sorcery and crime result from interpersonal relations inside the wider social group. The apparently natural ways of dying are in fact second degree cultural ways of dying resulting from inappropriate interactions with indwellers (Veyrié 2021, 167-168).

The radical difference between the unmarked dwellers - animals of the social group are not physically distinct - and indwellers is characterized by physical particularities, and even further by their sensitive qualities, to borrow an expression of Claude Lévi-Strauss $(1964,9)$. The indwellers themselves can be classified on two extremes of sensitive qualities from the point of view of organic life: Whirlwind and Ghost on the one hand are characterized by their limited materiality and the Ravine people and Canyons on the other by their excessive materiality. The different material valences of these characters can be appreciated in terms of the devices they display: the harmful power of Whirlwind comes from sorcery, the alleged damage he creates by action in the distance, without physical contact. On the other hand, the Ravine people and the Canyon monster are expressions of landscape features, and the violence they exercise on the animal characters, may it be by using the young Weasel as the projectile of a ballgame or by pounding people like food, is marked by crude imagery. These extreme monstrous characters can also be the expression of two narrative tools of the storyteller: a logic of the implicit focusing on suspense and interpersonal expectations, and a logic of the concrete in which crudity is key to expressing organic change - or transformation.

The members of these pairs are arguably variations on a cultural paradigm. First, the materiality of the enemy pair Ravine people - Canyon monster, sometimes represented as Nimizoho, a giant cannibal carrying a mortar or a basket on his back that he uses to grind people (Liljeblad 1986, 654) is enhanced by their opposite characters, the friendly Siwo?a, worms, that is to say skinless invertebrates, who, in another tale, inspire Coyote to make himself desensitized to bruising damage by tricking Nimizoho into pounding his empty hide (Kelly 1938, 410-411). The pounding of Coyote consists in treating him as the object of the cultural practice of cooking rather than the author of it, emphasizing an ultra-materialistic symbolic representation of the harm made to the people. The present story offers a variation on this action since the Canyon monster, the one who had the long feather on his head, is confident that the sick Coyote will not be able to hurt him, and accepts to be the first one to 
put his head on the rock to receive a blow. At any rate, the Siwo? a, skinless invertebrates, inspire Coyote to protect himself from the imminent bruising damage that can be expected from the Canyon monster. The explicit equation by Pete Snapp between this Canyon monster and tuberculosis shows that the same inversion as in the tale recorded by Isabel Kelly translated to disease - is effective here: instead of being the object of the disease (the headpounding), Coyote is the author of it. These variations illustrate a four-way symbolic space with predation and disease as axes: the cook, the food, the sick, and the strong, roles alternatively distributed and redistributed to Coyote and the Canyon monster. Worms appear as an absolute opposite to all four functions, in the sense of rendering them null, or rather, a point of transformation, the center of the symbolic quadrant. The body of Coyote is the ground where transformation between these roles takes place, the result of a tension between self-consciousness and a mysterious inner voice that seem to constitute the wisdom of social interdependency, personified by a parasite who depends on the body of a host to survive. The scale model to think of the relationship between Indigenous people and places appears in the responsibility of the Siwo?a to speak to his host Coyote and assist him with good thoughts; Paiute individuals have an ethical responsibility to talk to the natural world and ask for collective benefits, such as water, resources, social balance, or blessings, as McDermitt Paiute-Shoshone elder Herman Crutcher advocated in a speech (Veyrié 2021, 55-56).

The positions formally displayed in this quadrant are however not fixed, but in constant superposition and recomposition. The vertical axis ideally does not refer to an exploitative relationship, but to one based on reciprocity and trust. The horizontal axis represents body wellness with personal and social balance on the left, and salient materiality and selfishness on the right. The individual and social layers are mixed on this axis, and illness is most clearly expressed in its salient materiality. Old-time doctoring in North America emphasized the extraction of materialized illness from a patient body, in the form of a little object extracted by sucking the illness location (Park 1934, 105; Powell 1971, 245 on Paiute doctoring; LéviStrauss 1963, 186-205 on the efficiency of symbols). These two distinct axes are each clearly polarized, and they interact inside the body in mysterious ways of which inner feelings are a manifestation. Like when showing a point on a turning wheel, one is both alternatively and potentially always everywhere at the same time. 


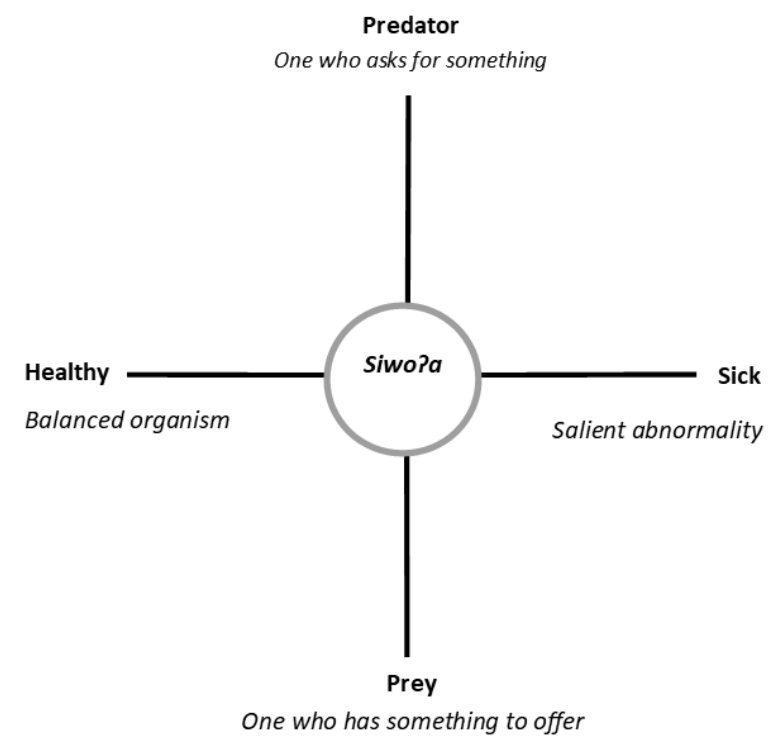

On the other end, whirlwinds are for Numic people the indication that something bad happened, often involving death (Lowie 1924b, 297; Hultkrantz 1986, 632). Whirlwind and Ghost, in their immateriality represent the invisible harm that can be caused, for example by sorcery and haunting. Ghost appears as an evil double of Coyote, sharing his deceptive tricks such as a friendship request to Coyote when he catches him, replicating his behavior and repeating the magic word. The insistence on the replication of their actions suggests treating them as alter egos, and while the physical presence of a ghost is undeniable in the story, the removal of his lungs and heart do not alter his functioning and he reveals himself to be unable to effectively hurt Coyote with Coyote's replicated weapon. The discrepancy between his morbid potential and his lack of effective power emphasizes how much of a psychological character Ghost, presented as the worst of all these rivals, is. Once Coyote declares that Ghost in fact has no power in a narrative performative speech act, Ghost simply disappears from the story, Coyote dispels his very existence. The harm that whirlwinds and ghosts can cause comes from speech: Paiutes do not talk about deceased people or about natural phenomena such as whirlwinds. One must respect mysterious creatures. The discrete dwellers should be 


\section{Thierry VEYRIÉ}

Monsters, Disaster, and Organic Balance: Digesting History Through Oral Traditions

left alone, and Coyote is here again acting as a cultural counterexample when he wishes canyons should be different. A functional explanation of the scary tales about cliffs and canyons and other places is that they are told to children to keep them out of trouble, but it is also the expression of a Native ontology of places that should be respected because they are loaded with memory and history.

The power of these eerie ultra-material or non-material dwellers is expressed through a poetics of materiality that is the evocation of the empirical effects that they can have on peoples' bodies and minds, may it be caused by a fall, by being smashed or dismembered, or haunted, corrupted or cursed. In the story, much of the trouble comes from Weasel accusing everybody for the loss of his younger brother in the ravine and being a threat to the community. Beatrice Blyth Whiting (1950), in Paiute Sorcery, explored how accusations of sorcery served the purpose of social control among the Wadatika. Here, Weasel threatens the balance of the group because the loss of his brother prompts him to suspect everyone of having directly or indirectly participated in his disappearance. Personal loss thusly affects the social body as a whole and requires a spiritual intervention to either physically or symbolically fill the void of the absence. This tale stages monsters emanating from disturbed landscape features, natural phenomena becoming personifications of disaster as well as the social disruption that they create among animals, metaphors of Paiute society.

One of the forms that the social chaos takes is diseases. Here we should note that disintegration occurs on different scales: First the environmental scale with Whirlwind, Ravine sometimes called "the hole in the earth" in the story, the ever crumbling rimrock, and Ghost, the anomaly that is a wandering spirit. Then, disintegration on the social scale has the self-destructive Weasel, the inefficiency of the Indian medicine men, and Coyote as leader by default. Third is the scale of the organic body affected by different forms of disintegration: dismemberment, disease, parasite, and vomit. Let us note also that none of the latter are intrinsically connoted negatively, but on the contrary can be media for transformation and change, illness can be acceptable if it has a personal or social purpose. As Betty Crutcher commented (Veyrié 2021, 266-268), everything in the body has a purpose. Peyote thus appears as a cleanser, a way to expel the accumulated illnesses in the Indian body, metonymy of Indian society.

The insistence on the different diseases brought by Coyote is particularly striking: while Pete Snapp uses the tale to do a typology of gonorrhea affirming that there are seven types of it, tuberculosis (passati?oipi, literally skinny or dry disease) is the object of a note on the right page of one notebook commenting "There is no old time Indian doctor who can treat it. But you can run it out if you run as fast as you can, you work it out of your system. [...] That is 
Thierry VEYRIÉ

Monsters, Disaster, and Organic Balance: Digesting History Through Oral Traditions

the Indian way-the Whites have them pray-but it's not much the White doctors can do for you." 19 This side comment by Pete Snapp highlights the contemporaneous relevance of the tale and invites looking at this tale as oral history told through myth and as an effort of transformation. In combining myth and history, this tale sharply illustrates the double temporality of myth theorized by Lévi-Strauss $(1955,430)$ : at the same time diachronic and synchronic. While Pete Snapp's reference to contemporaneous events allows the listener to place the tale in a suite of events, the use of mythical sequences reveals its everlasting quality, a character of eternal truth allowing to transcend the contingency of time. Let us now better identify the events Pete Snapp is storytelling.

\section{Oral History Told Through Myth}

Tuberculosis is not entirely new to the American continent but there is no doubt that EuroAmerican settlers, including the Spanish, the Anglo, the French and other early travelers and migrants brought new strains for which Native people had little immunization (Prat 2003). Similarly, sexually transmitted infections became more common among Native communities in historic times. While syphilis - not reliably distinguished from gonorrhea until the end of the $19^{\text {th }}$ century - existed in aboriginal America, this perhaps was not a venereal disease (Powell and Cook 2005). Gonorrhea was probably brought to the Americas with European colonization, and the fact that Pete Snapp used a borrowing from English to name the disease suggests that the disease was unknown to the Paiutes until Europeans arrived. In this instance, we can see that storytelling can serve the purpose of sex education and the prevention of sexually transmitted infections, and through the counterexample of Coyote, the promotion either of monogamous sex or abstinence. The emphasis on disease in this tale is not a negligible detail, organic wellness is one of the narrative threads of the story. The demography of the Native people of the Great Basin, including the Northern Paiutes, saw a sharp decline in the 1870's that reached its minimum in 1930 and slowly started increasing after that date (Leland 1986, 608). Apart from the Paiute-Bannock uprising of 1878, which gathered about 300 men, and the subsequent Yakima exile, Indian wars were over after 1870. This demographic decline was caused by diseases and other social issues, including depression at the social level. Sarah Winnemucca $(1883,48)$ wrote in 1883 that: "My people have been so unhappy for a long time they wish now to disincrease, instead of multiply". My 
thesis here is that Pete Snapp in this tale performs Native history and strikingly depicts the Native social collapse, the spread of infectious diseases, high mortality rate that he witnessed most his life, and a turn to a new hope for the community. The arrival of the Peyote in 1934 coincides with a demographical shift reinforcing this medicine as representing renewal. This tale by Pete Snapp told a few years before his death works as a life story, rendering the changes he witnessed during his life through the art of traditional storytelling.

In representing physical decay and social decadence, Pete Snapp describes a collapsing world. The time of myth, explaining how the chaos became the order that we know today is thus epistemologically relevant to render the end of the old world and the beginning of a new Native world partly based on the old one. Another anthropological aspect of this myth is the loss of social structures in three main aspects: 1) Kinship, Coyote sleeps around, threatening the social balance of the Northern Paiute group focused on extended families; 2) Religion, Medicine Men have lost their power and they are not only unable to cure diseases but they are also helpless in facing sorcerers who cause dissension. This common statement, also reported by Willard Zerbe Park $(1934,98)$, is expressed in the story by Weasel who curses everyone and causes harm to the group because he has lost his younger brother, the Medicine Men being ineffective at solving the problem. The story of a sorcerer cursing everybody and threatening society after the death of his son appears also in an oral history account by Captain Louey from the neighboring Paiute band of the Wadatika (Marsden 1972, 48-49). In it, he said he witnessed the curse when he was a child and hundreds of people including his mother die by "bleeding from the nostrils." Pete Snapp's seminal Weasel episode could be a retelling of the same account of a tuberculosis epidemic caused by the arrival of new strains carried by white explorers and traders. The arrival of epidemics is interpreted as the act of sorcerers and the inability of medicine men to cure them causing disbelief in traditional medicine; 3) Politics, the tale is also striking by the absence of one crucial character of Numic folklore, which is Wolf. Wolf and Coyote are usually alter egos, the first one being a responsible leader and the second the power hungry disrupter. Ghost acts as one of Coyote's alter egos in this story, which can be a singular expression of morbid leadership. The broken promises of friendship from Ghost could suggest that he refers to Euro-Americans, but they are otherwise entirely absent of the tale. Wolf's absence is also partially compensated by the Siwo? a, but they are internal to Coyote, one could say prisoner, and must witness his erratic behavior, powerless. The absence of leadership, or worse, Coyote's leadership, expresses the despair of the absence of a reliable leader in chaotic times. In these three ways, Pete Snapp's story is a Native perspective on the post-contact history of the Northern Paiutes of the Oregon-Nevada area. 
This tale also promotes the Native American Church as a revitalization movement. According to Omer Stewart, an anthropologist who started studying this movement only two years after it began in Northern Paiute country, "The purpose of the cult is to heal and to protect through the worship of God by means of peyote. [...] Peyote serves as an intermediary [and is commonly referred to] as a 'medicine', a 'power', a 'protector', or a 'teacher'." Consumption of alcohol is prohibited for peyotists, and they are compelled to value love, hope, charity, ambition, and honesty. During the Peyote Ceremony, practitioners congregate in codified prayer meetings lasting all night during which participants undergo cleansing through consumption of the peyote, fanning, use of blessed water, and a communal meal (Stewart 1944, 64-5). The values of organic renewal performed during these ceremonies serve a social purpose in addition to a spiritual one. Northern Paiute communities have been victim of disease, alcohol, and drug epidemics and have been harmed by the loss of social structures. Corbett Mack, a Tabooseedokado Paiute elder interviewed by Michael Hittman, shared the same analysis as Pete Snapp that Peyote came to save the Paiutes from illnesses, but that in order to be powerful, it should not be mixed with any other drug or spiritual system (Hittman 1996, 201-5). The arrival of this new Indian medicine filled a need for healing and coincided with the rise of a new generation that had not known pre-reservation period but that was looking for practices that celebrated Indigenous identity and resilience. Harm, disease, and trauma, seen as materialized illnesses in one's body, can be expelled in the ceremony of the Peyote, the consumption of the cactus often causing vomiting later in the night. Once again scales are imbricated, and the individual body serves as a metonymy of society. The latter can be healed by curing the first.

The adoption of Peyote by Northern Paiutes was certainly not unanimous and prompted many reactions from enthusiasm to condemnation. Its relative success, among certain people in some communities, can in part be explained by its cultural relevance on three ideas preexisting in Paiute culture: 1) A similar organic aesthetics of healing is present in PaiuteShoshone oral traditions and in the Native American Church. 2) Renewal through collective worship already existing in messianic movements such as the Ghost Dance, 3) The eagerness for new Indigenous medicines, most repeatedly expressed in Pete Snapp's story. On the other end, others resisted and condemned this new religion because it competed with strictly local spirituality based on the relationship to places and the power that they contained. Imported religions, even Indigenous ones, distracted people from the relationships they were expected to maintain with local powers: a tension between the rights of indwellers to be considered and the collective renewal through imported powers is prevalent in Pete Snapp's tale. In addition, as in the case of Oitsi's advocacy for the Dreamer movement, suspicion of witchcraft affected peyotists (Stewart 1944, 82), a pattern also alluded to by Pete Snapp when 
he refers to Weasel's paranoid accusations. Even if the Native American Church in McDermitt started as a minority movement, the social cohesion it produced eventually became popular in much of the community. As in other communities where it was taken up, it brought social stability and personal benefits that ramified in McDermitt society at large.

\section{Organic Frameworks}

Here I will briefly discuss the relevance of the Native American Church in the McDermitt community history. Although this article does not focus on Native spirituality, the arrival of Peyote is important from an ethnohistorical point of view, because it corresponded roughly with the formal constitution of the Fort McDermitt Paiute-Shoshone Indian Tribe in 1934. Omer Stewart synthesized the anthropological explanations of the success of Peyote in Native communities on the basis of two distinct reactions, the cultural compatibility theory, according to which Peyote was successful because it fit existing cultural expectations, and the cultural disintegration theory, according to which it was successful because it filled the space left by sociocultural disruption (Stewart 1944, 89-94). Certainly, Pete Snapp is most explicitly a proponent of the latter. Like in the case of Oren George's presentation of Temoke's words regarding the making of the Treaty of 1863 (Veyrié 2021, 45-48), we can see here that Pete Snapp condenses in his account both views of the controversial event of the arrival of Peyote, but in Pete Snapp's case he also made clear on which side of the controversy he stood by saying that Peyote was the only one who had power any more. However, I would like to defend here that the adoption of Peyote, like other Paiute religious movements, can be interpreted as the organic integration of a new element by the social body, a process that itself includes both disintegrative and accommodative dynamics. Anthony Wallace (1970) most famously described the revival movement led by the Seneca Handsome Lake under the organic framework of death and rebirth. By conceptualizing this Indigenous expression in organic terms, we may conceive that oral traditions can provide a vocabulary to contextualize, understand, and process social suffering (Geertz 1973, 105).

More recently, Daniel Swan proposed to use various approaches including the historical materialist theory - akin to Stewart's disintegration theory - to describe the adoption of the Big Moon variant of the Peyote religion by the Osage as "a gradual process of trial and revision in which a new sense of the social order and spiritual harmony was instituted" (Swan 1998, 67). Following Fogelson (1989, 134-135), Swan challenged the idea that the arrival of the Big Moon was a singular event, but rather a gradual community-based conceptualization of historical consciousness culminating in "a revolutionary, transformative movement" for 
Osage society. This process is described by Swan as the result of the cohabitation between the Osage and the Quapaw between 1874 and 1889, resulting in the formal adoption of the Big Moon by the Osage in 1904-1906. In Nevada, although the Paiutes had heard about the spread of the Peyote in the 1920's (Stewart 1944, 69), and no doubt Indigenous travelers had been exposed to it prior to these dates, the Peyote religion arrived in Northern Paiute country from the east in the 1930's, and several roadmen started regular meetings. ${ }^{20}$ In Pete Snapp's story, although the social disruptions preexisting the arrival of Peyote are described at length, Peyote is mentioned at the end as a solution, but without gradual community exposure. It appears as a providential person, certainly interpretable in historic terms, but as an agent capable of change and a brighter future for the community. The community deliberation of the need for a new, different medicine is however also at the heart of the story, in part similarly to the way it surfaces in Swan's discussion of the Osage, when the community discussed the roadman John Wilson: "They said that he was one of the most powerful men. He had more power than any of them" (Swan 1998, 62). Among the Osage as among the Paiutes, at least as can be interpreted in Pete Snapp's tale, the question of the community's adoption of the Peyote was deliberated in comparing the efficiency of the old and the new powers. In Pete Snapp's tale however, Peyote is himself the personified power, whereas in Swan's description the named roadman, John Wilson, mediates the relationship with the powerful medicine, but this could simply be imputable to the genre of myth.

Jason Baird Jackson traced the different reactions to Peyote to an existing divide between cosmologies of power in Indigenous societies between the High Plains and the Great Basin on the one hand, and the Southeast on the other. Specifically, traditional power in the Plains and Great Basin tends to be acquired from places - also to some extent at birth and death whereas among the Yuchi in the Southeast, extensive study and apprenticeship with elders appears to be the way of acquiring power (Jackson 2004, 198-201). According to Jackson, Peyotism conformed more closely to Yuchi beliefs than other revitalization movements such as the Ghost Dance that relied on performing the visionary experiences of a chosen man. Among the Yuchi, Jackson presents the Native American Church as a practice that developed on already existing sociopolitical structures and spirituality rather than as a religious revolution. As corn farmers and given their experience of displacement in the 1830's, the Yuchi welcomed the arrival of a new medicine within their existing traditions. This opposite interpretation to Swan's relies on a cosmological divide between the Indigenous American 
West and the Woodlands where the Native American Church was not a social revolution. The importance of the personified emanations of landscape as expression of power in Pete Snapp's tale, the disruption of these existing networks of relationships between the people and the indwellers, and the final declaration that a more powerful one has arrived to lead the people suggests that the Native American Church was a more fundamental challenge to Great Basin Indigenous belief systems than it was in the Southeast. However, this tale also emphasizes that an organic model of the sociopolitical body can ensure cultural continuity even through social disruption. Even if the Indigenous Great Basin has a deep relationship to places - bounded grounds and their social world - this relationship is also characterized by organic adaptation, symbiotic coexistence, and as such, a propensity to accept and enact change.

The argument that I support in my interpretation of this tale narrated by Pete Snapp is that the arrival of Peyote was a political and historical controversy for the Paiutes at McDermitt not unlike the Ghost Dance was for the Lakota in the Plains between Fall and Winter 1890 as described by Raymond DeMallie (1982). Namely, I argue that Pete Snapp presents in this tale a reading of the historical events he witnessed during his life through a resolutely Indigenous perspective, using a worldview "of the relationship between mankind and the natural world [...] to understand these changes from the Lakota perspective" (DeMallie 1982, 390), but here applied to the Paiute. In this process, symbolic or interpretive anthropology is an important tool, because we need to conceptually reconstitute the different viewpoints expressed in the Native community without imposing expectations and concepts of EuroAmerican society.

As we saw, the spiritual and political dynamics present in this tale can be interpreted as a continuation of the ancient spiritual and sociopolitical Paiute paradigm according to which certain specialists or speakers can mediate the relationship between individuals and the social group, without however possessing authority outside of the bounded space in which they are trusted to guide activities. In a context in which the acquisition of curative power from relationships with indwellers occupying certain places had grown more uncertain because of the disruption on the land, the Native American Church constituted a way to continue spiritual mediation. The arrival of a new power however did not invalidate all the other preexisting spiritual entities, but provided them with new leadership: "You should help the person, who is a good medicine man, when he is healing somebody" says Coyote to Ghost.

The two approaches to understanding new religious movements mentioned by Omer Stewart - cultural compatibility and cultural disintegration - are compatible, because they allow for a view of social transformation, continuity through change. Sometimes an excessively 
formalistic approach to cultural phenomena leads us to forget that social interactions are made of relationships, ways of relating, distinct and sometimes competing forces. In addition, the social group is not monolithic, and antagonistic dynamics coexist in any integrated system. Thus, to conceptualize the reaction of the Paiute to novelty, I promote the use of organic frameworks, diversified but interconnected autonomy of a sentient organism continuing through time by absorption and transformation. Such organic model may also apply to Great Basin sociopolitical structures (Veyrié 2021, 315-347).

\section{Conclusion}

Pete Snapp's multi-episodic tale narrates a quest for remedy in a time of disorientation and loss of power. The disasters that it covers are the expression of historical events that affected the Paiute throughout the $19^{\text {th }}$ century and into the $20^{\text {th }}$ century even as it is also a mythical narrative about the formative period in Paiute cosmology. The tale also expresses an organic aesthetics of the material body in focusing on processes such as disease, pounding, dismemberment, vomiting, parasites, flaying, needling and more. They express the social torment of a collapsing world but also set the grounds for a renewed organic ideology that precisely uses organic mechanisms as cleansing and healing. In other words, as the bodies of this tale's characters represent society, the connection established between the body and society reveals reciprocal as the purification of the body allows to heal society.

Although I argue that this tale is rich in ethnohistorical content, it is also devoid of any clear reference to contact with white people. Perhaps, as Cailín Murray $(2019,63)$ argued in the case of the Wild Man narratives in the Pacific Northwest, the monsters of Pete Snapp's tale are boundary keepers, at the same time relational beings and expressions of a malaise in Indigenous space. But this absence is also is a reminder for us that Native people are not obsessed with the arrival of the white people, like we too often assume. Indigenous cultures are not defined in opposition to non-indigenous cultures. In this tale, it is expressed as a continuing and autonomous relation to land with the capacity of absorbing novelty. Cultural relativism, the axion of sociocultural anthropology since Franz Boas, demands the study of cultures in their own terms. It seems suited to characterize revitalization movements in the terms of organic frameworks since the Native individuals who describe them consistently use the aesthetics of organic life to model cultural change.

Pete Snapp uses myth as a synchronic device capable to process and support history. Monsters are metaphorical expressions of trauma in addition to be pedagogical devices of 
Thierry VEYRIÉ

Monsters, Disaster, and Organic Balance: Digesting History Through Oral Traditions

warning. The polysemy, the thickness of oral tradition cannot be salvaged in its entirety, but it is our duty as anthropologists, especially if we are interested in the ethnohistorical approach, to restitute the complexity of oral history. Parole carries personal and collective structures: we never express as genuinely what haunts us as when using speech freely.

\section{References Cited}

Bahr, Donald M. 2001. "Bad News: The Predicament of Native American Mythology." Ethnohistory 48 (4): 587-612.

DeMallie, Raymond J. 1982. "The Lakota Ghost Dance: An Ethnohistorical Account." The Pacific Historical Review 51 (4): 385-405.

Descola, Philippe, and Janet Lloyd. 2013. Beyond nature and culture. Chicago and London: The University of Chicago Press.

Fogelson, Raymond D. 1989. "The Ethnohistory of Events and Nonevents." Ethnohistory 36 (2): 133-47.

Fogelson, Raymond D. 1980. "Windigo Goes South: Stoneclad among the Cherokees." In Manlike Monsters on Trial: Early Records and Modern Evidence, edited by Halpin, Marjorie M, and Michael M Ames, 132-151. Vancouver: University of British Columbia Press.

Foster, Michael Dylan. 2008. Pandemonium and Parade: Japanese Monsters and the Culture of Yokai. Berkeley: University of California Press.

Geertz, Clifford. 1973. The Interpretation of Cultures: Selected Essays. New York: Basic Books.

Halpin, Marjorie M, and Michael M Ames, eds. 1980. Manlike Monsters on Trial: Early Records and Modern Evidence. Vancouver: University of British Columbia Press.

Hittman, Michael. 1996. Corbett Mack the Life of a Northern Paiute. Lincoln: University of Nebraska Press.

Hultkrantz, Åke. 1986. "Mythology and Religious Concepts". In Handbook of North American Indians, 630-640. Vol. 11 of Great Basin, edited by Sturtevant, William C., and Warren L. D'Azevedo,. Washington D.C.: Smithsonian Institution.

Jackson, Jason Baird. 2004. "Recontextualizing Revitalization: Cosmology and Cultural Stability in the Adoption of Peyotism among the Yuchi." In Reassessing Revitalization Movements: Perspectives from North America and the Pacific Islands, edited by Harkin, Michael Eugene, 183-205. Lincoln: University of Nebraska Press.

DOI: 10.2478/eas-2021-0021 @ University of SS. Cyril and Methodius in Trnava. All rights reserved. 
Jackson, Jason Baird. 2013. "The Story of Colonialism, or Rethinking the Ox-Hide Purchase in Native North America and Beyond." Journal of American Folklore 126 (499): 31-54.

Kelly, Isabel T. 1938. "Northern Paiute Tales." The Journal of American Folklore 51 (202): 363-438.

Leland, Joy. 1986. "Population" In Handbook of North American Indians, 608-619. Vol. 11 of Great Basin, edited by Sturtevant, William C., and Warren L. D'Azevedo,. Washington D.C.: Smithsonian Institution.

Lévi-Strauss, Claude. 1955. "The Structural Study of Myth." The Journal of American Folklore 68 (270): 428-444.

Lévi-Strauss, Claude. 1963. Structural Anthropology. New York: Basic Books.

Lévi-Strauss, Claude. 1964. Mythologiques 1 : Le Cru et le Cuit. Paris: Plon.

Liljeblad, Sven S. 1986. "Oral Traditions: Content and Style of Verbal Arts." In Handbook of North American Indians, 641-659. Vol. 11 of Great Basin, edited by Sturtevant, William C., and Warren L. D'Azevedo,. Washington D.C.: Smithsonian Institution.

Lowie, Robert Harry. 1909. The Northern Shoshone. New York: Anthropological Papers of the American Museum of Natural History.

Lowie, Robert Harry. 1915. "Oral Tradition and History." American Anthropologist 17 (3): 597-599.

Lowie, Robert Harry. 1924a. "Shoshonean Tales." Journal of American Folklore 37 (143/144): 1-242.

Lowie, Robert Harry. 1924b. Notes on Shoshonean Ethnography. New York: Anthropological Papers of the American Museum of Natural History.

Marsden, W. L. 1923. The Northern Paiute Language of Oregon. Berkeley: University of California Press.

Marsden, W. L. 1972. Notes on Northern Paiute Ethnography: Kroeber and Marsden Records, edited by Robert F. Heizer, Thomas R. Hester, and Michael J. P. Nichols. University of California, Berkeley: Archaeological Research Facility.

McMillan, Alan D, and lan Hutchinson. 2002. "When the Mountain Dwarfs Danced: Aboriginal Traditions of Paleoseismic Events along the Cascadia Subduction Zone of Western North America." Ethnohistory 49 (1): 41-68.

Mori, Masahiro. 2012. "The Uncanny Valley." IEEE Robotics and Automation Magazine 19 (2): 98-100. 
Murray, Cailín. 2019. "Locating the Wild Man: Rainforest Enchantments and Settler Colonial Fantasies Amid the Ruins of the Anthropocene." Journal of Historical Sociology, Modern Monsters, Special Edition 32 (1): 60-73.

Musharbash, Yasmine. 2014. "Introduction: Monsters, Anthropology and Monster Studies." In Monster Anthropology in Australasia and Beyond, edited by Yasmine Musharbash and Geir Henning Presterudstuen, 1-24. New York: Palgrave Macmillan.

Park, Willard Z. 1934. "Paviotso Shamanism." American Anthropologist, 36 (1): 98-13.

Powell, John Wesley. 1971. Anthropology of the Numa: John Wesley Powell's Manuscripts on the Numic Peoples of Western North America, 1868-1880, edited by Don D. Fowler and Catherine S. Fowler. Washington D.C.: Smithsonian Contributions to Anthropology.

Powell, Mary L., and Della C. Cook. 2005. The Myth of Syphilis: The Natural History of Treponematosis in North America. Gainesville: University Press of Florida.

Steward, Julian Haynes. 1936. Myths of the Owens Valley Paiute. University of California Publications in American Archaeology and Ethnology 34 (5), 355-444. Berkeley: University of California Press.

Stewart, Omer Call. 1944. "Washo-Northern Paiute Peyotism, a Study in Acculturation," University of California Publications in American Archaeology and Ethnology 40 (3), 63142. Berkeley: University of California Press.

Stewart, Omer Call. 1987. Peyote Religion: A History. Norman: University of Oklahoma Press.

Swan, Daniel C. 1998. "Early Osage Peyotism.” Plains Anthropologist 43 (163): 51-71.

Trejo, Judy. 1974. "Coyote Tales: A Paiute Commentary." The Journal of American Folklore 87 (343): 66-71.

Vansina, Jan. 1985. Oral Tradition as History. Madison: University of Wisconsin Press.

Veyrié, Thierry. 2021. A Historical Ethnography of the Fort McDermitt Paiute-Shoshone. Doctoral dissertation, Department of Anthropology. Bloomington: Indiana University.

Wallace, Anthony F. C., and Sheila C. Steen. 1970. The Death and Rebirth of the Seneca. New York: Knopf.

Winnemucca Hopkins, Sarah. 1883. Life among the Piutes Their Wrongs and Claims. New York: G.P. Putnam's Sons of New York.

Whiting, Beatrice Blyth. 1950. Paiute Sorcery. New York: Johnson. 


\section{Thierry VEYRIÉ}

Monsters, Disaster, and Organic Balance: Digesting History Through Oral Traditions

Thierry Veyrié is Research Associate at the American Indian Studies Research Institute (Indiana University - Bloomington) and Language and Traditional Culture Manager for the Burns Paiute Tribe in eastern Oregon. He started conducting fieldwork in Northern Paiute communities in 2012 when he was preparing his Master's degree in sociocultural anthropology at the École des Hautes Études en Sciences Sociales (Paris, France). Between 2014 and 2021, while he was a Graduate Research Fellow and Instructor at Indiana University, he intermittently conducted field research in the oral traditions of the Fort McDermitt Paiute-Shoshone community, recording new Paiute testimonies and translating existing recordings with Elders of the community. In 2017-2018, Veyrié spent thirteen months in McDermitt with the support of several significant grants including

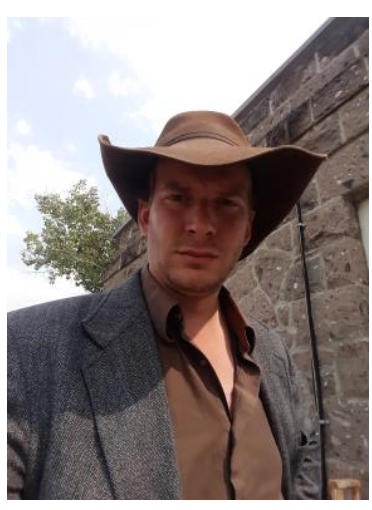
one from the Documenting Endangered Languages program of the National Science Foundation (BCS-1723388) and one from the Lewis and Clark Fund for Exploration and Field Research. His doctoral dissertation, A Historical Ethnography of the Fort McDermitt Paiute-Shoshone (2021, Anthropology Department, Indiana University), draws both from Paiute oral traditions and from the military correspondence held at the U.S. National Archives to propose an ethnohistory of the McDermitt community. Dr. Veyrié is actively involved in the revitalization and maintenance of the endangered Northern Paiute language and has been since a collaborative workshop he organized with McDermitt Elders that produced Wayadeaga Apegan, Language of the Rye-Grass Valley: A Booklet Containing Materials to Preserve and Transmit the Paiute language (2018). 